\title{
Technical Notes on Participation on balloting process of ASTM International
}

by Karel Pospíšil, CDV - Transport Research Centre, karel.pospisil@cdv.cz

\section{Introduction}

ASTM International is one of the largest voluntary standards development organizations in the world. It is a trusted source for technical standards for materials, products, systems, and services. There are over 130 ASTM technical committees covering diverse industry areas ranging from metals to the environment. The author of the technical note is a voting member of five of them. They are:

- Committee C09 on Concrete and Concrete Aggregates

- Committee D04 on Road and Paving Materials

- Committee D18 on Soil and Rock

- Committee D35 on Geosynthetics

- Committee E07 on Non-destructive Testing

Above mentioned committees balloted about 394 documents, see Table 1.

\begin{tabular}{|c|r|r|r|r|r|}
\hline & \multicolumn{5}{|c|}{ Number of Ballots } \\
\hline Ballot & $\begin{array}{c}\text { Committee } \\
\text { C09 }\end{array}$ & $\begin{array}{c}\text { Committee } \\
\text { D04 }\end{array}$ & $\begin{array}{c}\text { Committee } \\
\text { D18 }\end{array}$ & $\begin{array}{c}\text { Committee } \\
\text { D35 }\end{array}$ & $\begin{array}{c}\text { Committee } \\
\text { E07 }\end{array}$ \\
\hline $1 / 09$ & 49 & 45 & 25 & 24 & 39 \\
\hline $2 / 09$ & 28 & 3 & 11 & 14 & 30 \\
\hline $3 / 09$ & 38 & 23 & 16 & 8 & - \\
\hline $4 / 09$ & 21 & 1 & 11 & - & - \\
\hline $5 / 09$ & 1 & 3 & - & - & - \\
\hline $6 / 09$ & 4 & - & - & - & - \\
\hline Sum in the Committee & 141 & 75 & 63 & 46 & 69 \\
\hline Total Sum in Specified 5 Committees & & & 394 & & \\
\hline
\end{tabular}

Table 1: Number of Ballots in Specified Committees

The technical note would like to inform about the new standards or their revisions in the mentioned committees in 2009.

\section{Committee C09 on Concrete and Concrete Aggregates}

The committee was balloting about new standards or revisions of test methods for e.g. resistance to degradation of large-size coarse aggregate by abrasion and impact in the Los Angeles machine, for bond strength of adhesive systems used with concrete as measured by direct tension, for self leveling mortars containing hydraulic cements, for slump flow of self-consolidating (compacting) concrete, for passing ability of selfconsolidating concrete by J-ring, for air content of freshly mixed concrete by the pressure method, for flexural strength of concrete (using simple beam with third-point and center-point loading), for microscopic determination of parameters of the air-void system in hardened concrete, for electrical indication of concretes ability to resist chloride ion 
penetration, for water-soluble sulfate in soil, for restrained expansion of shrinkagecompensating concrete, for potential alkali reactivity of cement-aggregate etc.

In the same time the Committee was busy with preparation of specifications, such as for coal fly ash and raw or calcined natural pozzolan for use in concrete, for fiber-reinforced concrete and shotcrete, for chemical admixtures for concrete, cold-weather admixture systems, for packaged, dry, combined materials for mortar and concrete, ready-mixed concrete etc.

The committee was voting about many guides, practices and other documents regarding to concrete and concrete aggregate.

\section{Committee D04 on Road and Paving Materials}

Asphalt and bituminous materials have taken large part of the committee effort. The test methods, specifications and other documents referred to them. Some documents were targeted to base and subbase materials and their testing.

\section{Committee D18 on Soil and Rock}

Besides test methods, guides and other documents very big effort of the committee was aimed to practice such as for minimum geospatial data for an abandoned mine land problem area, for minimum geospatial data for underground coal mining extents, for description and identification of soils visual-manual procedure, for classification of soils and soilaggregate mixtures for highway construction purposes, decontamination of field equipment used at low level radioactive waste sites.

\section{Committee D35 on Geosynthetics}

Needed test methods, guides, practices and other documents was discussed in the committee, e.g. for trapezoid tearing strength of geotextiles, for strength of sewn or thermally bonded seams of geotextiles, for measuring mass per unit area of geotextiles, for static puncture strength of geotextiles and geotextile-related products using a 50-mm probe, for determining tensile properties of geogrids by the single or multi-rib tensile method, for abrasion resistance of geotextiles sand paper/sliding block method, for determining filtering efficiency and flow rate of the filtration component of a sediment retention device using site-specific soil etc.

\section{Committee E07 on Non-destructive Testing}

Radiographic and radioscopic methods were widely discussed in the committee. Besides them guides, practices and test methods aimed to other NDT methods where balloted, such as for the pulsed longitudinal wave ultrasonic examination of metaland metal alloy production material, for electromagnetic eddy-current examination of copper and copper-alloy tubes, for quality management systems for nondestructive testing agencies, for terminology for nondestructive examinations etc.

\section{Summary and Acknowledgement}

Information about ASTM International can be obtained form their website www.astm.org. Author's participation in ASTM International is partly supported by the grant of the Ministry of Education, Youth and Sports of the Czech Republic no. LA 09007. 